\title{
Paleolatitudes and magnetostratigraphy for Cenozoic sediments, ODP Leg 182: The Great Australian Bight
}

\author{
Roberto S. Molina Garza ${ }^{1}$ and Mike Fuller ${ }^{2}$ \\ ${ }^{1}$ Unidad de Investigación en Ciencias de la Tierra, UNAM Campus Juriquilla, Querétaro, 76230, Mexico \\ ${ }^{2}$ Hawaii Institute of Geophysics and Planetology-SOEST, University of Hawaii, Honolulu, HI 96822, U.S.A.
}

(Received April 13, 2001; Revised November 22, 2001; Accepted December 11, 2001)

\begin{abstract}
Cenozoic northward drift of the Australian plate was determined from paleomagnetism of Middle Eocene through Pleistocene sediment cores from ODP Leg 182 (Sites 1126, 1128, and 1134) in the Great Australian Bight. Paleolatitude estimates are based on stepwise AF and thermal demagnetization of $\sim 400$ discrete samples, of which $\sim 250$ provided reliable data. The characteristic magnetization of the sediments resides in magnetite and magnetic sulfides. Middle Eocene through Lower Oligocene $(\sim 36 \mathrm{Ma})$ paleolatitudes of $\sim 52^{\circ}\left( \pm 2^{\circ}\right)$ change gradually to Late Miocene $(\sim 9 \mathrm{Ma})$ paleolatitudes of $\sim 48^{\circ}\left( \pm 2^{\circ}\right)$. These data, combined with Australian paleomagnetic pole data, indicate a slow rate of northward motion through much of the Cenozoic ( $\sim 28 \mathrm{~mm} / \mathrm{yr})$. These data also indicate an abrupt acceleration in the Late Miocene (drift rate $\sim 115 \mathrm{~mm} / \mathrm{yr}$ ), coinciding with tectonic events in Southeast Asia. Paleolatitude estimates support Miocene versions of the Australian apparent polar wander path that place the Oligocene-Miocene pole ( $\sim 25 \mathrm{Ma}$ ) at $\sim 70^{\circ} \mathrm{S}-125^{\circ} \mathrm{E}$ and the Late Miocene pole at $\sim 70^{\circ} \mathrm{S}-105^{\circ} \mathrm{E}$ (e.g., Idnurm, $1985,1994)$. Inclination data for discrete samples also provide a refined magnetostratigraphy for portions of the Miocene, Oligocene, and Eocene carbonate and siliciclastic section of the Great Australian Bight.
\end{abstract}

\section{Introduction}

Leg 182 of the Ocean Drilling Program (ODP) was undertaken in the shelf, slope, and continental rise of the Great Australian Bight (Fig. 1), a passive continental margin developed after separation of Antarctica and Australia. The main objectives of Leg 182 were the study of sedimentologic-biostratigraphic-paleoclimatic- and paleoceanographic records of the development of the Southern Ocean and the evolution of a cool-water carbonate platform (Shipboard Scientific Party, 2000).

Northward drift and clockwise rotation of the Australian continent as it separated from Antarctica had a profound impact on the evolution of Southern Ocean and Cenozoic paleoclimate. The drift history of the Australian continent is also important for reconstructing the tectonic evolution of Southeast Asia and understanding the closure of the Indonesian seaway. Australia's drift history can be reconstructed using paleomagnetic data; the apparent polar wander path (APWP) is built for this purpose. The accuracy of the APWP in describing plate motion is necessarily dependent on the availability and quality of the paleomagnetic data. In the case of Australia this is a contentious issue. Existing versions of the Australian APWP indicate $\sim 35^{\circ}$ of northward drift since the Late Cretaceous. Competing paths differ, however, in their interpretation of the rate of APW (Musgrave, 1989; Idnurm, 1994; Embleton and McElhinny, 1982; Fig. 2). Although different methodologies were used in constructing competing paths, the dif-

Copy right (C) The Society of Geomagnetism and Earth, Planetary and Space Sciences (SGEPSS); The Seismological Society of Japan; The Volcanological Society of Japan; The Geodetic Society of Japan; The Japanese Society for Planetary Sciences. ferences between them reflect primarily varying data selection criteria. Idnurm (1985) considers, for example, unreliable most data for Eocene through Miocene volcanic rocks widespread in eastern Australia. In contrast, these data were partially filtered by Embleton and McElhinny (1982), whereas Musgrave (1989) includes the entire volcanic rock data in a least-square fit of the path. Musgrave's (1989) approach to APWP definition and calibration provides estimates of the position and age of the pole along a polynomial fit. Because a least-squares criterion is used in the polynomial fit, the approach will successfully remove the effect of random errors, and results in a high degree of smoothing.

Only recently, has the paleomagnetic record of deep-sea sediments been used to place constraints in APWPs of major plates (Klootwijk et al., 1991; Kodama and Ogg, 1992; Acton, 1999). The record of Australia's plate motion contained in Cenozoic sediments recovered on ODP Leg 182 provide the means to better define Australia's APWP. This record exists in the form of a depositional remanent magnetization from which the magnetic inclination and paleolatitude at the time of deposition can be recovered. In addition, a magnetic polarity stratigraphy may provide absolute ages, and thus the means to accurately calibrate the rate of (northward) motion of the sampling sites.

Paleocolatitudes estimated from inclination data from drill cores constrain the locus of the paleomagnetic pole along a small-circle centered at the drilling site. Kodama and Ogg (1992) provided Late Jurassic to Paleogene paleolatitudes for the northwest Australian plate using paleomagnetic results of Sites 765 and 766 of Leg 123 along with Site 261 of Leg 27 . We present here paleomagnetic data for 


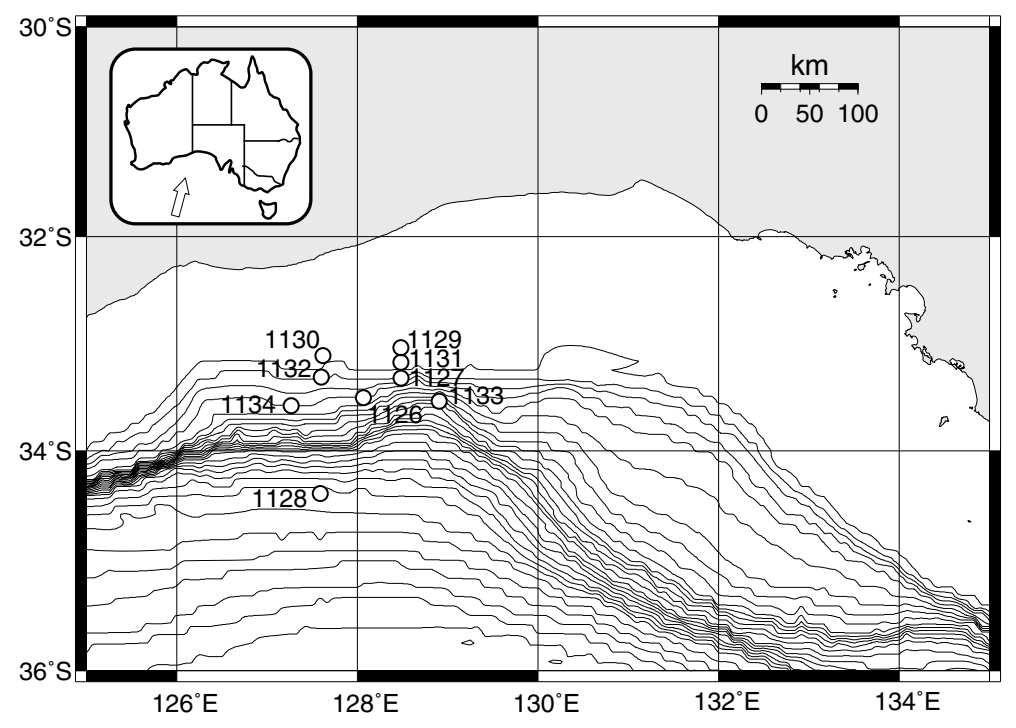

Fig. 1. Location of drill sites of ODP Leg 182 in the Eyre Terrace of the Great Australian Bight. Contours indicate water depth.

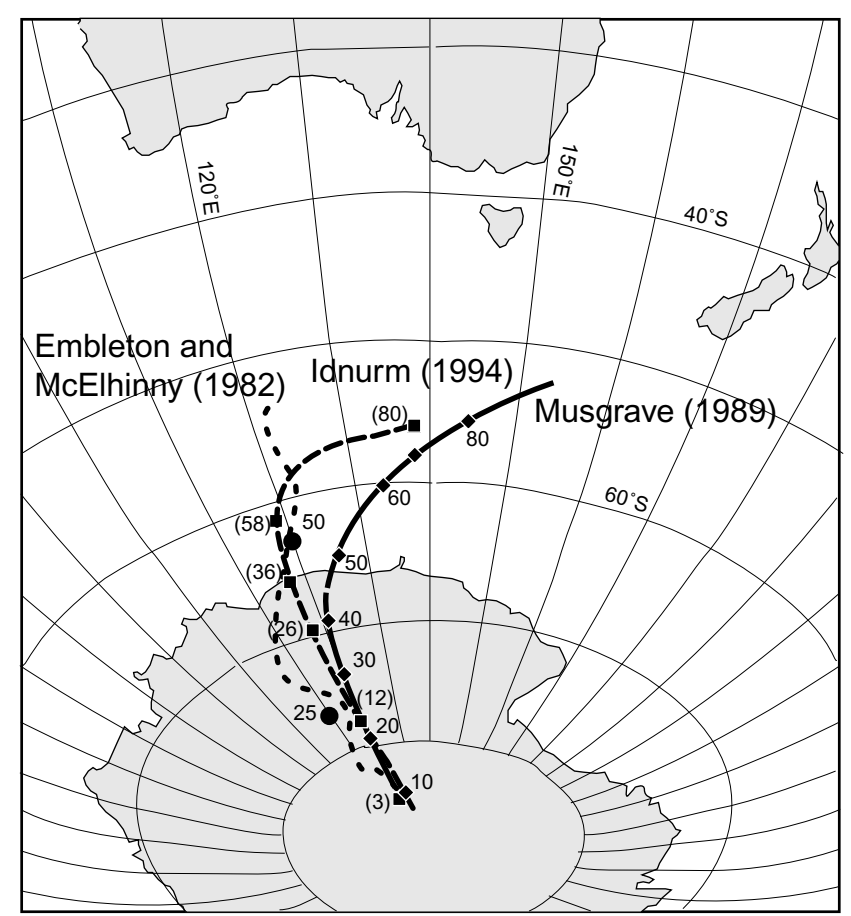

Fig. 2. Competing version of the Australian APWP. The APWPs are: Embleton and McElhinny (1982), (2) Musgrave (1989), and (3) Idnurm $(1985,1994)$. The numbers indicate approximate age of the reference (south) pole.

Cenozoic sediments recovered from sites 1126, 1128, and 1134 of ODP Leg 182 in the Great Australian Bight (Feary et al., 2000). These data provide a detailed record of the Cenozoic (northward) drift history of the Bight and yield a magnetostratigraphy that, with limitations, can be correlated to the global polarity time scale (GPTS) for parts of the Late Miocene to Middle Eocene. These data are used to test the validity of competing models of the Australian APWP.

\section{Methodology}

We report paleomagnetic results for shore-based studies of discrete samples and also summarize relevant data for shipboard long-core measurements. Details of the methodology and results of long-core measurements carried out onboard the JOIDES Resolution were published in the Initial Reports of Leg 182 (Feary et al., 2000). Core sections of archive halves were measured at 5 or $10 \mathrm{~cm}$ intervals and subjected to blanket alternating field (AF) demagnetization up to $20 \mathrm{mT}$ using the in-line coil system of a $2 \mathrm{G}$ Enterprises DC-SQUID superconducting magnetometer. This was generally sufficient to completely remove any drilling-induced overprint, as shown by on-board measurements of discrete samples. Long-core measurements are the basis for magnetostratigraphic interpretations.

Estimates of paleolatitudes are solely based on measurements of discrete samples. For this purpose, $7 \mathrm{~cm}^{3}$ plastic cubes (1-2 per section) were collected from working halves of selected drill cores at the Gulf Coast Core Repository shortly after the cruise. Cubes of $\sim 10 \mathrm{~cm}^{3}$ volume were cut from partially lithified marine clays and carbonate rocks. Prior to laboratory analysis samples were kept inside a magnetic shield in a refrigerated room. A small number of samples $(\sim 20 \%)$ were collected during the cruise and an even smaller number $(\sim 5 \%)$ were measured on board the JOIDES Resolution.

Most samples were subjected to progressive AF demagnetization with AF peak inductions of up to $130 \mathrm{mT}$; maximum AF used on discrete samples measured on the ship were about $40 \mathrm{mT}$, but for some AF treatment was continued on-shore. A few specimens were subjected to thermal demagnetization up to $530^{\circ} \mathrm{C}$. For the characterization of the magnetic mineralogy, samples were imparted anhysteretic as well as isothermal magnetizations (ARM and IRM, respectively). Hysteresis parameters were obtained for selected specimens using a MicroMag vibrating sample magnetometer. Sample magnetizations were measured with a $2 \mathrm{G}$ Enterprises RF-SQUID superconducting magnetometer 
hosted in a shielded room at the paleomagnetic laboratory of the University of New Mexico using the in-line AF coil system. A small number of samples were measured with a similar magnetometer at the University of Hawaii.

The vectorial composition of the natural remanent magnetization was determined from inspection of vector demagnetization plots (Zijderveld, 1967). Directions were calculated using conventional principal component analysis (PCA) after Kirschvink (1980). Mean inclinations were calculated for different time intervals, and, where present, the means of normal and reverse polarity inclinations were compared to provide an approximate reversal test (McFadden and McElhinny, 1990). The magnetic tensor tool (MTT) was used to orient some piston cores (APCs), but it was of little use to determine mean declinations. Declinations either exhibit large scatter or cluster in the direction of the fiducial mark (the arbitrary $0^{\circ}$ declination), an observation attributed to acquisition of a drilling induced magnetization. The method of McFadden and Reid (1982) was applied to obtain an unbiased estimate of the mean inclination and associated uncertainty. Paleolatitudes were calculated assuming the geocentric axial dipole hypothesis.

\section{Geologic Setting and Sampling 3.1 Site 1126}

Site 1126 is located on the eastern Eyre Terrace (Fig. 1). Recovered materials consist mostly of calcareous ooze, slumped calcareous sediments, and minor layers of porcellanite and chalk. Siliciclastic sediments of probable Cenomanian age were collected at the base of the drilled interval. The latter lack age-diagnostic fossils; the Cretaceous age is based on a correlation with marine deposits recovered from exploration borehole Jeroba I (Feary et al., 2000). Nannofossil and planktonic biostratigraphies indicate Middle Eocene through Quaternary ages for the calcareous sediments overlying Cretaceous strata. The Cenozoic section is rather incomplete and several hiatuses or disconformities exist. Eocene through Miocene sediments were sampled in Hole $1126 \mathrm{~B}$, starting at depths of about $62 \mathrm{mbsf}$ (meters below sea floor). A distinct lithologic boundary in Section 182-1126B-8H-3 ( $67 \mathrm{mbsf}$ ) separates Pliocene from Upper Miocene assemblages; this boundary has been interpreted as a disconformity (Feary et al., 2000). Cores $9 \mathrm{H}$ through $14 \mathrm{H}$ recovered Upper Miocene sediments, whereas Cores $15 \mathrm{H}$ though $19 \mathrm{H}$ recovered Middle Miocene strata. Below Core $19 \mathrm{H}$ recovery was poor. Lower Miocene sediments were sampled in Cores 1126D-3R to 6R and Upper Oligocene sediments were sampled in Cores 1126B-27X to $29 \mathrm{X}$ and $1126 \mathrm{D}-8 \mathrm{R}$ to $11 \mathrm{R}$ ( $\sim 215-255 \mathrm{mbsf})$. Finally, Middle Eocene sediments were sampled in Cores 1126D-24R to 26R ( 368-408 mbsf).

\subsection{Site 1128}

Site 1128 is located on the continental rise, south of Site 1126 (Fig. 1). Recovered materials are unlike sediments recovered in shallow and intermediate water depths. They consist of calcareous ooze, gravity flow deposits and turbidites, calcareous clay, claystone, siltstone, sandstone, and minor intervals of chert and chalk. We sampled primarily and expanded section of Lower Oligocene through Middle Eocene siliciclastic and calcareous sediments that underlie an upper Miocene (?) debrite interval. Samples were collected in Hole 1128B from Cores 1128B-5H through 27X ( 36.5-245.6 mbsf), as well as Hole 1128C from Core 5H to $15 \mathrm{H}$ (38.7-138.2 mbsf). Middle Eocene sediments were also obtained from Cores 1128D-1R though 22R ( 232.0$435.5 \mathrm{mbsf}$ ).

\subsection{Site 1134}

Site 1134 was drilled in the Eyre Terrace west of site 1126 (Fig. 1) at similar water depth. Sites 1126 and 1134 exhibit similar assemblage compositions, ages of recovered sediments, and general position of hiatus, but Site 1134 was the only site with good recovery through the Miocene interval. Sediments recovered consist of calcareous ooze and partially lithified wackestone/packestone, as well as minor amounts of porcellanite and chalk. Eocene sandstones were recovered at the base of the drilled interval. Sampling concentrated in Middle and Late Miocene sediments from Cores 1134A-7H through 14H ( 52.8-111.2 mbsf) and 1134B-6H through $13 \mathrm{H}(\sim 52.2-119.9 \mathrm{mbsf})$.

\section{Paleomagnetic Results \\ 4.1 Site 1126}

Long-core measurements of sediments of Site 1126 aboard the JOIDES Resolution were disappointing. Due to the low intensity of the magnetization, long-core records of inclination are noisy and do not provide unique correlations to the GPTS. Natural remanent magnetization (NRM) intensities range between $1 * 10^{-3}$ and $1 * 10^{-4} \mathrm{~A} / \mathrm{m}$, but $80 \%$ of the measurements after $20 \mathrm{mT}$ AF demagnetization correspond to values $<1 * 10^{-4} \mathrm{~A} / \mathrm{m}$ (Feary et al., 2000). For intervals that produce interpretable results, long-core measurements of the NRM and AF demagnetization reveal that the sediments carry an overprint of steep positive inclination (Fig. 3(a)). After removal of this magnetization, generally with $\mathrm{AF}$ of $\sim 10 \mathrm{mT}$, we recognized a steep to moderate inclination magnetization that is interpreted as the characteristic magnetization (ChRM).

Section 5 of Core 14H (Fig. 3(a)) shows the typical demagnetization behavior observed throughout Hole 1126. NRM intensity, which is low already, drops sharply after AF treatment. The magnetization removed is steep and positive, as mentioned above, isolating a magnetization of moderately steep negative inclination. Commonly, however, magnetizations remaining after $20 \mathrm{mT} \mathrm{AF}$ are of low inclinations (positive and negative); these are of course anomalous for the latitude of the site and are considered spurious. Declinations are primarily centered on the $0^{\circ}$ value (the fiducial orientation mark). In intervals of weak intensities and spurious magnetizations it was impossible to recover a ChRM. Shallow inclinations are not limited to intervals of low intensities. A $\sim 20 \mathrm{~cm}$ thick interval on the top of the section exhibits anomalously high intensities and also shallow inclinations (Fig. 3(a)). We speculate these high intensities are caused by disturbance or contamination during core handling.

The fact that declinations cluster around the $0^{\circ}$ declination value must be an artifact, because the fiducial line inscribed in the core liner is of arbitrary orientation. Several models have been proposed to explain this observation, and it is likely that a single explanation may not apply in all 


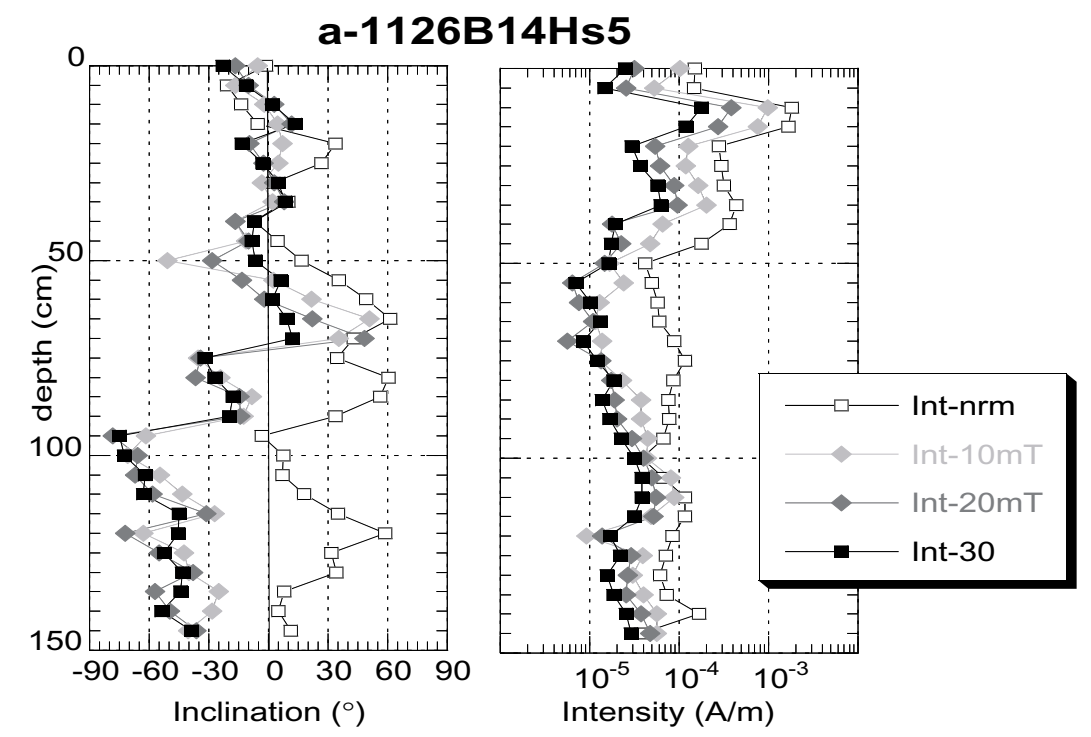

b-1128B 12Hs5-6
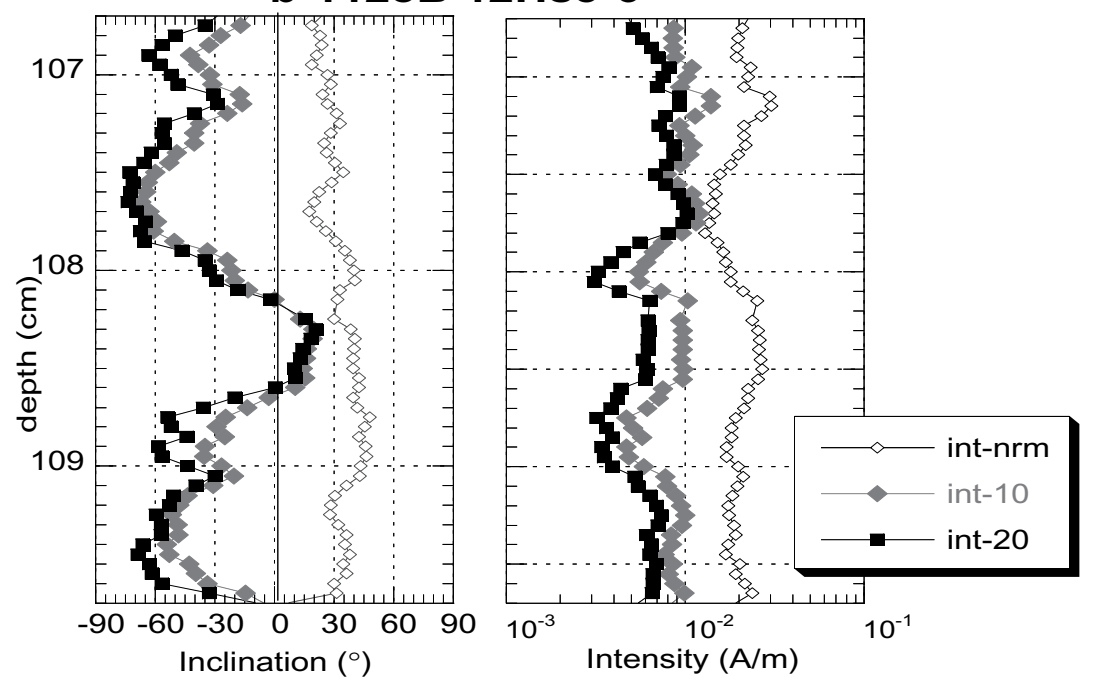

Fig. 3. (a) Results of long-core measurements of Section 5 of Core 1126B-14H, before and after AF demagnetization. measurements of Sections 5 and 6 of Core 1128B-12H, before and after AF demagnetization.

cases. One explanation favored by many is the presence of a horizontal radial component directed inward induced while coring. Because measurements are carried on a half core, a radial component would manifest a small bias in the $+X$ direction in sample coordinates. A more detailed discussion of drilling induced overprints is presented in Fuller et al. (2000).

We studied a total of 97 discrete samples from Site 1126, 25 of them in Hole 1126D and the rest in Hole 1126B. Intensities for 18 of these samples are too low to be measured reliably and 5 samples had erratic demagnetization (neither the direction of the ChRM nor its polarity are interpretable). In the remaining samples, we generally observed two components of magnetization (Figs. 4(a)-(b)). In piston-cored sediments a soft steep downward-directed magnetization was removed with $\mathrm{AF}$ of $\sim 10 \mathrm{mT}$ isolating a ChRM of moderate to high coercivity. Numerous investigations of the magnetic fields in the various components used in coring and pipe have shown these to be relatively strong and capable of magnetizing the sediments, providing a simple explanation for the overprint observed here. In sediments extracted with a rotary drill the overprint was generally directed upward (Fig. 4(e)) suggesting that the bottom-hole assemblage can strongly influence the orientation of drilling induced overprints. Maximum AF required to remove the ChRM rarely exceed $100 \mathrm{mT}$, but we often observed noisy decay of the magnetization at AF peak inductions $>40 \mathrm{mT}$. This behavior is attributed to acquisition of anhysteretic remanences (ARMs; Figs. 4(b) and (f)). When this type of behavior was observed, the direction of the ChRM was calculated anchoring line segments to the origin, using demagnetization steps above $15 \mathrm{mT}$ but below the onset of unstable behavior. Otherwise, unanchored segments were used to estimate the ChRM direction.

Median destructive fields (MDFs, the induction required to reduced the intensity of the NRM to half its initial value) range between about 15 and $40 \mathrm{mT}$ with generally lower values in deeper cores; occasionally MDF values are as high as $50 \mathrm{mT}$. Thermal demagnetization shows that the ChRM is stable in intensity and direction up to temperatures of 

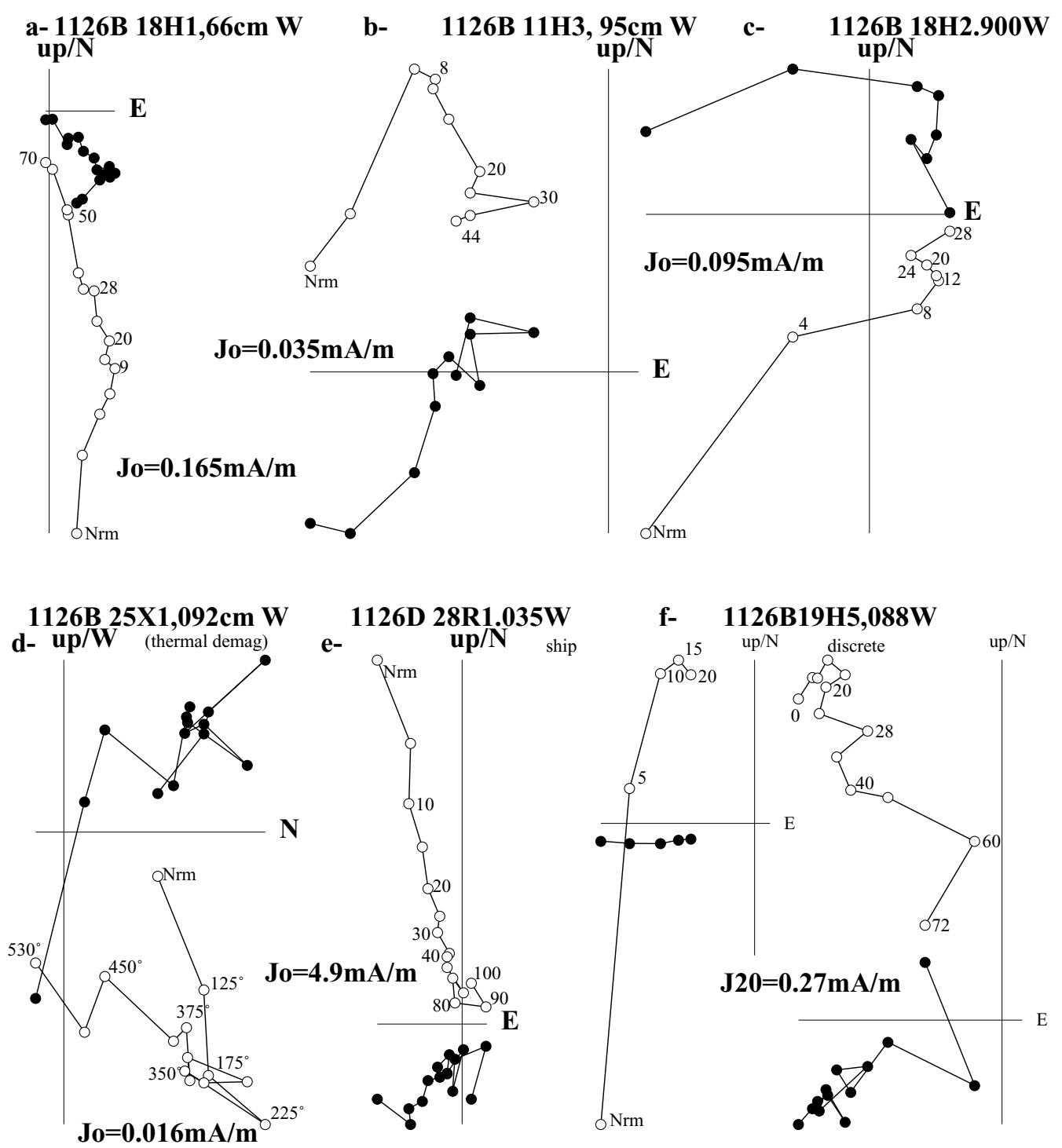

Fig. 4. (a)-(f) Orthogonal demagnetization plots of typical specimens of Site 1126. Open (closed) symbols are projections on the vertical (horizontal) plane.

$\sim 400^{\circ} \mathrm{C}$ (Fig. 4(d)). Maximum unblocking temperatures exceed $530^{\circ} \mathrm{C}$ but cannot be determined more precisely because demagnetization behavior is typically erratic above $450^{\circ} \mathrm{C}$. We attribute the erratic behavior to alteration of the magnetic mineralogy during thermal demagnetization and acquisition of spurious remanences in the laboratory. This is supported by significant increases in magnetic susceptibility observed above $400^{\circ} \mathrm{C}$.

Samples with stable linear decay to the origin were rated A; 22 of the 97 samples show this behavior (e.g., Figs. 4(a) and (e)). When a significant ARM was observed during demagnetization experiments but the direction of the ChRM was recovered, samples were rated B (e.g., Figs. 4(b) and (f)); 34 of the 97 samples had this behavior. In 18 samples, the polarity (but not the direction) of the magnetization remaining after removal of the overprint can be interpreted from demagnetization trajectories (Fig. 4(c)); these, as well as samples with MAD (maximum angular deviation) values $>10^{\circ}$ were rated $\mathrm{C}$. MAD values for $\mathrm{A}$ and $\mathrm{B}$ samples used in paleolatitude estimates average $5.9^{\circ}$.

Inclination of the ChRM of both long-core and discrete sample measurements for segments of Hole 1126B are plotted against depth in Figs. 5 and 6. Also plotted is the preferred correlation of the observed polarity zonation to the GPTS. As explained earlier, direct and unambiguous correlation to the GPTS is not possible, but tie lines are reasonably constrained by available biostratigraphic data and inferred sedimentation rates. Correlation to the GPTS is further complicated by breaks in sedimentation evident as debrite intervals, slumps, or missing biozones (marked in Fig. 5 as sedimentation breaks). In Cores 1126B-9H and $10 \mathrm{H}$ ( 75 to $85 \mathrm{mbsf}$ ) we identify a sequence of thin normal and reverse polarity zones that can be correlated to chron $\mathrm{C} 3 \mathrm{n}$ (correlation with other intervals, such as C3An is not supported by available biostratigraphic data; Fig. 5). The polarity zonation of Cores $1126 \mathrm{~B}-11 \mathrm{H}$ and $12 \mathrm{H}$ (92-106 mbsf) may correlate with the chron sequence $\mathrm{C} 5 \mathrm{n}$ or $\mathrm{C} 4 \mathrm{n}$. Correlation with chron $\mathrm{C} 5 \mathrm{n}$ is preferred; biozone NN11 

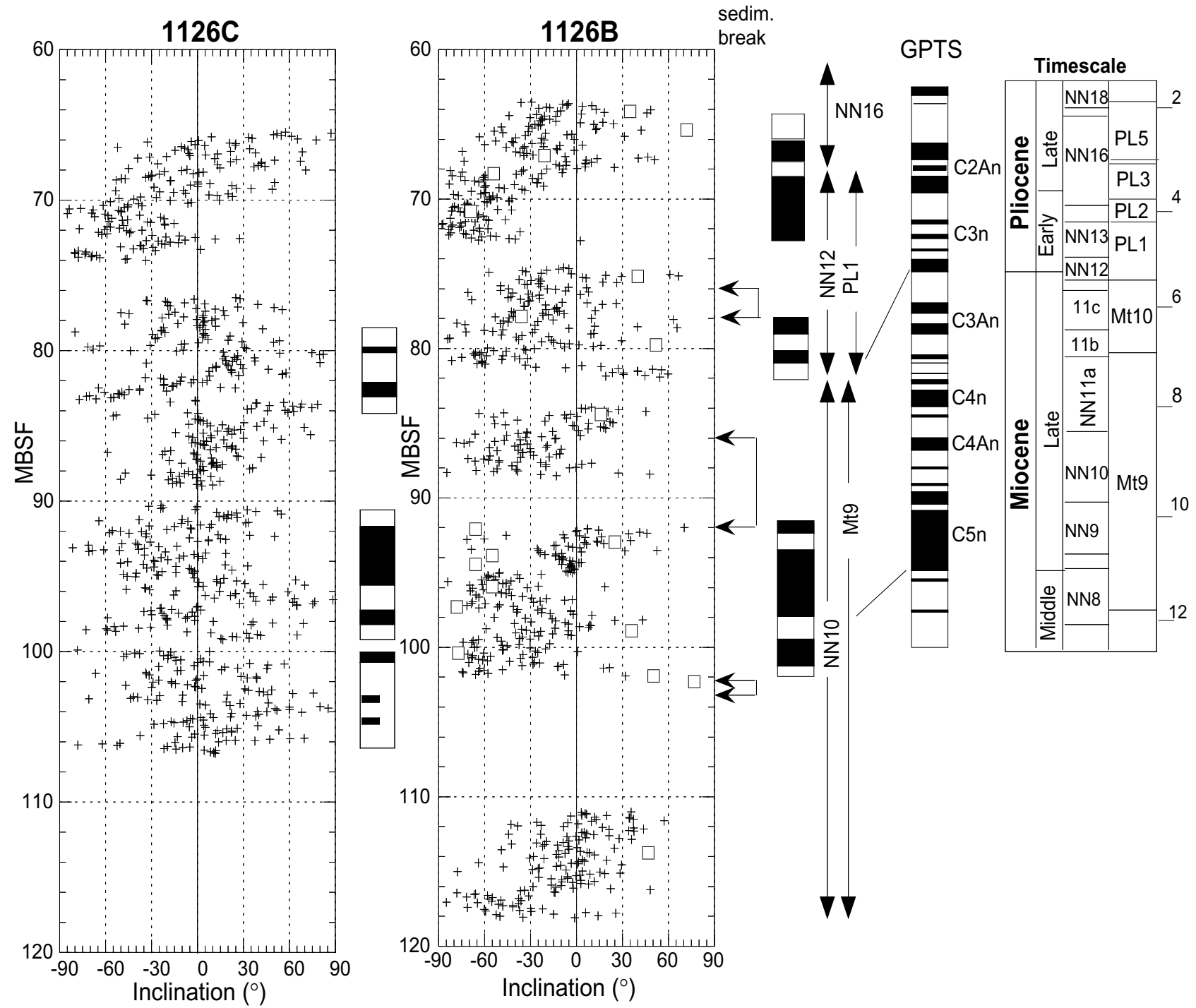

Fig. 5. Magnetostratigraphy results for the Upper Miocene interval of Site 1126B. In this and subsequent figures, the polarity time scale and biozonation are after Berggren et al. (1995). In this and subsequent figures, cross symbols are long-core measurements and open squares are measurements on discrete samples. The arrows indicate sedimentation breaks in the section.

is absent suggesting the presence of a hiatus that contains chron $\mathrm{C} 4 \mathrm{n}$.

The quality of the record improves in cores $17 \mathrm{H}$ and $19 \mathrm{H}$ (Fig. 6). This Middle Miocene interval is characterized by a thick zone of reverse polarity in Core $17 \mathrm{H}$ and the top of $18 \mathrm{H}$, and a well-defined sequence of 4 thin intervals of reverse polarity and 3 zones of normal polarity in Core $19 \mathrm{H}$. Data for Core $18 \mathrm{H}$ are less reliable, and measurements of discrete samples did not improve the definition of polarity zones. Correlation to the GPTS (Fig. 6) is also tentative but the best agreement is obtained when the interval recovered in cores $17 \mathrm{H}$ to $19 \mathrm{H}$ is correlated with the series $\mathrm{C} 5 \mathrm{Er}$ to C5ADn (Fig. 6). The biozonation, however, does not support this correlation. An alternative that is more consistent with the biozonation is shown with a dashed tie line in Fig. 6. In this alternative, the sequence of short normal and reverse magnetozones in Core $19 \mathrm{H}$ is correlated with chron $\mathrm{C} 5 \mathrm{Cn}$. The correlations indicate that the age of the Miocene intervals sampled in Site 1126 ranges between $\sim 14$ to $19 \mathrm{Ma}$ and $\sim 9$ to $11 \mathrm{Ma}$ (Cande and Kent, 1995). Paleolatitude data are discussed below.

\subsection{Site 1128}

Site 1128 provided by far the best paleomagnetic data. Long-core measurements of Lower Oligocene claystone, siltstone, and calcareous clays revealed a detailed polarity stratigraphy that can be readily correlated with the series of reversals C10n to C18n of the GPTS. These are recorded in a section $\sim 400 \mathrm{~m}$ thick indicating an average (but slightly variable) sedimentation rate of $3.4 \mathrm{~cm} / \mathrm{kyr}$.

Materials recovered in Site 1128 exhibit relatively high NRM intensities $\left(\sim 1 * 10^{-2} \mathrm{~A} / \mathrm{m}\right)$. Long-core measurements show that $\mathrm{AF}$ of $\sim 10 \mathrm{mT}$ is sufficient to remove drillinginduced secondary magnetizations. Inclination (and intensity) records show clear sub-meter-scale periodicity that may reflect paleosecular variation (Fig. 3(b)). Furthermore, smooth but well-defined intensity decreases accompany polarity transitions. Declinations, however, are again anomalously clustered around the arbitrary $0^{\circ}$ value. 


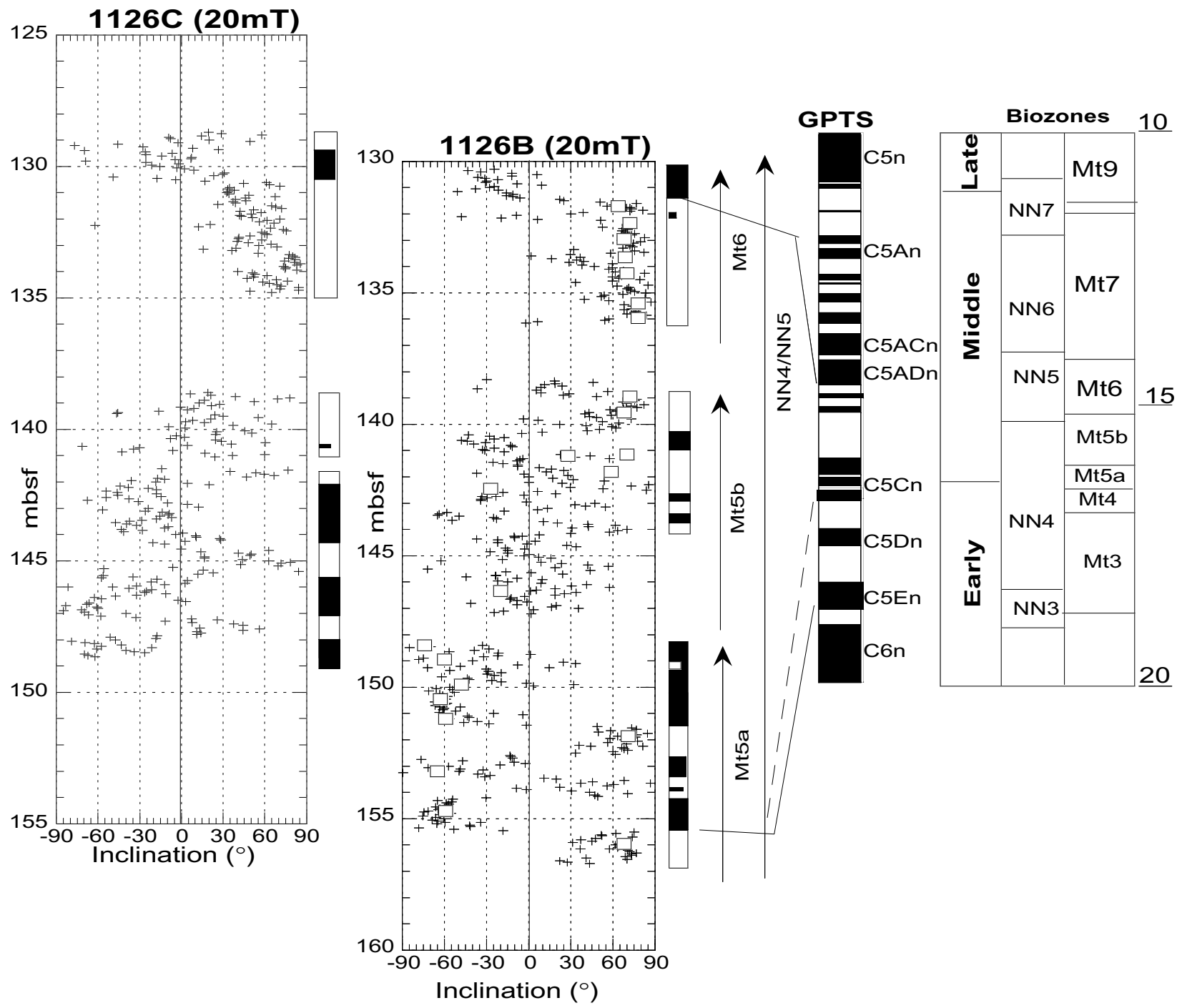

Fig. 6. Magnetostratigraphy results for the Middle Miocene interval of Site 1126. Two possible correlations to the GPTS are shown by solid and dashed lines.

We collected a total of 214 discrete samples, primarily from Holes 1128B (127 samples) and 1128D (68 samples). Twenty-two samples show unstable demagnetization behavior or the intensity of the magnetization is below the magnetometer's noise level. Progressive AF demagnetization of discrete samples removes soft magnetizations that overprint the ChRM. Overprinting magnetizations are mostly steep positive (Fig. 7(a)) but steep negative (Fig. 7(b)) and shallow spurious overprints were also observed (Fig. 7(c)). The ChRM decays to the origin but as in Site 1126 spurious ARMs were acquired at high AF peak inductions (Figs. 7(b) and 7(e)). In some samples maximum coercivities exceed $100 \mathrm{mT}, \sim 10 \%$ of the initial NRM remains at that demagnetization level (Fig. 7(e)). MDFs range between about 20 and $40 \mathrm{mT}$ with generally lower values in deeper cores. Thermal demagnetization isolates a ChRM of identical direction to that isolated with AF. The ChRM is of distributed unblocking temperatures with a rapid decay between 75 and $300^{\circ} \mathrm{C}$ (Fig. 7(f)). Maximum unblocking temperatures are undetermined because no sample kept physical coherence upon heating to $550^{\circ} \mathrm{C}$.
For site $1128 \mathrm{~B}$, the great majority of the samples analyzed are rated $\mathrm{A}(33 \%)$ or $\mathrm{B}(35 \%)$. MAD values for $\mathrm{A}$ and $\mathrm{B}$ samples used in paleolatitude estimates average $5.7^{\circ}$. Measurements of discrete samples confirm the magnetostratigraphy determined for long-core data. The correlation of the polarity zonation of Site 1128 sediments to the GPTS (Fig. 8) is straightforward. This polarity zonation contains the distinctive long reversed intervals of the Early Oligocene (in perfect agreement with biostratigraphically determined ages) as well as two short normal polarity intervals that include a shorter reverse subchron; these are unquestionably chrons $\mathrm{C} 10 \mathrm{n}$ and $\mathrm{C} 11 \mathrm{n}$ with their respective tops at $\sim 75$ and 100 mbsf. Poor recovery in Hole 1128D hinders precise correlation to the GPTS but the dominant normal polarity is indicative of Middle Eocene chrons C17n and C18n.

\subsection{Site 1134}

Paleomagnetic data for Site 1134 are of marginal quality. We collected a total 81 samples from Holes 1134A and $1134 \mathrm{~B}$, of which $\sim 50 \%$ did not provide useful data. Long-core measurements had characteristics similar to Site 1126, AF demagnetization resulted in declinations clus- 


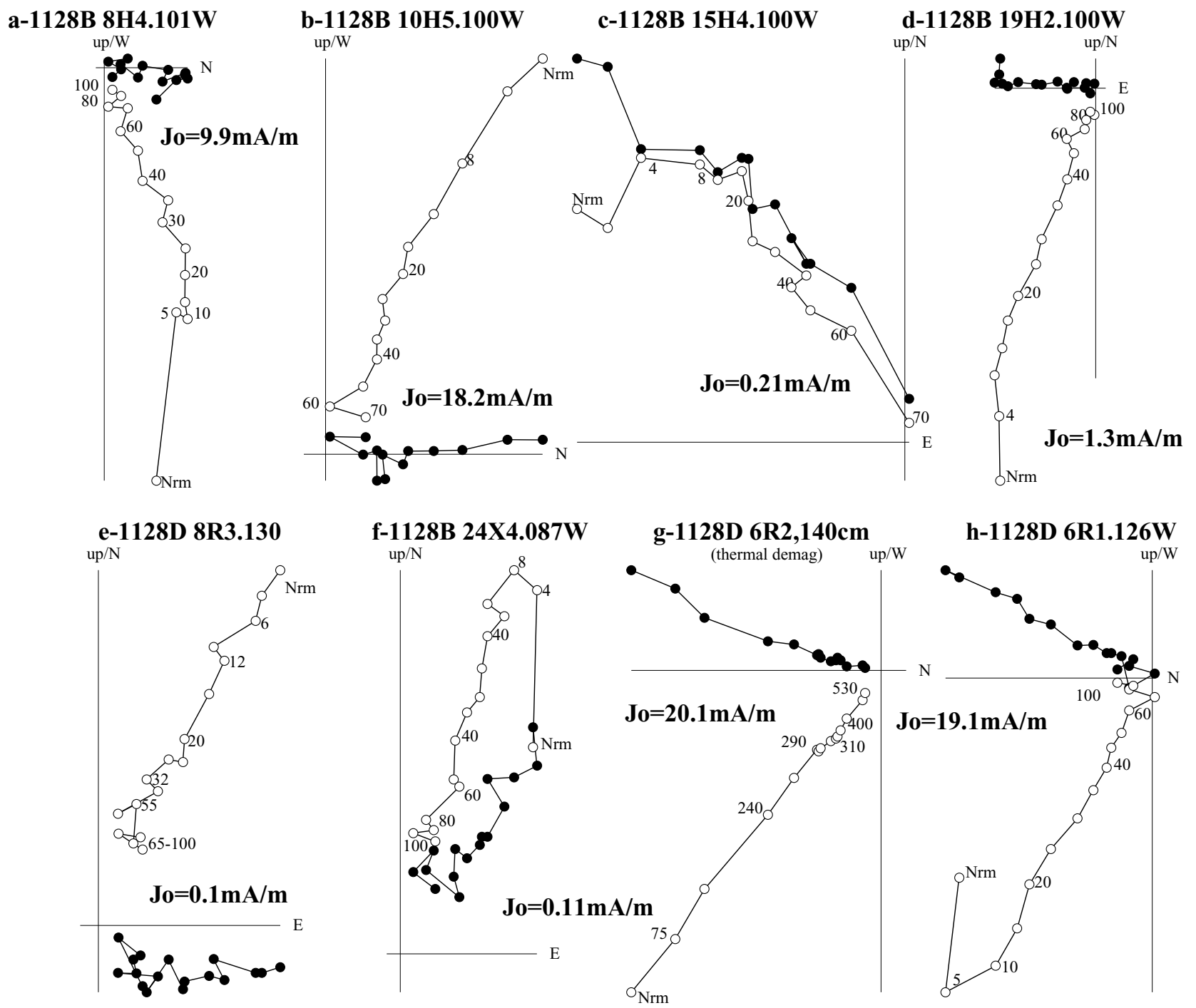

Fig. 7. (a)-(h) Orthogonal demagnetization plots of typical specimens of Site 1128. Open (closed) symbols are projections on the vertical (horizontal) plane.

tered around the fiducial mark and several intervals exhibit anomalously low inclinations. The intensity of the NRM is low; the upper $120 \mathrm{~m}$ of sediments have a median NRM of $\sim 0.2 \mathrm{~mA} / \mathrm{m}$. Progressive AF demagnetization of discrete samples shows that the NRM is overprinted by a steep downward directed magnetization that is removed with AF of $<10 \mathrm{mT}$ (Fig. 9(a)). After removing this overprint, demagnetization diagrams define near-linear trajectories that often miss the origin, possibly due to the combined effect of a weak remanence and background noise due to the instrument's sample holder and drift (Figs. 9(a) and 9(b)). In many cases, a soft overprint is the only interpretable magnetization (Fig. 9(c)).

Only 18 samples yield good estimates of both the direction and polarity of the ChRM (A or B behavior); the polarity could be determined in 20 additional samples that were rated C. Despite the low quality of the data, measurements on discrete samples allowed refinement of the magnetic polarity interpretations presented in the Initial Results volume (Shipboard Scientific Party, 2000).
Figure 10 shows that the interval between $\sim 65$ and $\sim 110$ mbsf, which contains microfossils indicating a Late Miocene age (foram biozone Mt10 and nanofossil zones NN10-NN12), contains a reversal pattern consistent with that of chrons $\mathrm{C} 3 \mathrm{Bn}$ to $\mathrm{C} 3 \mathrm{An}$. This polarity stratigraphy hinges on results for discrete samples from cores $7 \mathrm{H}$ to $11 \mathrm{H}$. Figure 10 also shows the correlation of the polarity stratigraphy of the interval between $\sim 155$ and 115 mbsf to the Middle Miocene sequence including chrons $\mathrm{C} 5 \mathrm{Bn}$ to $\mathrm{C} 5 \mathrm{ACn}$. This correlation is also supported by biostratigraphic data. In summary, Figure 10 suggest that the interval for which we obtained reliable paleolatitude data at Site 1134 is limited to $\sim 6$ to $8 \mathrm{Ma}$.

\section{Magnetic Properties}

\subsection{Sites 1126 and 1134}

Available rock magnetic data include coercivity and unblocking temperature of the NRM, alternating field and acquisition of ARM and IRM, and limited hysteresis data. Magnetic properties of sediments from Sites 1134 and 1126 are quite similar. Key observations include low NRM in- 

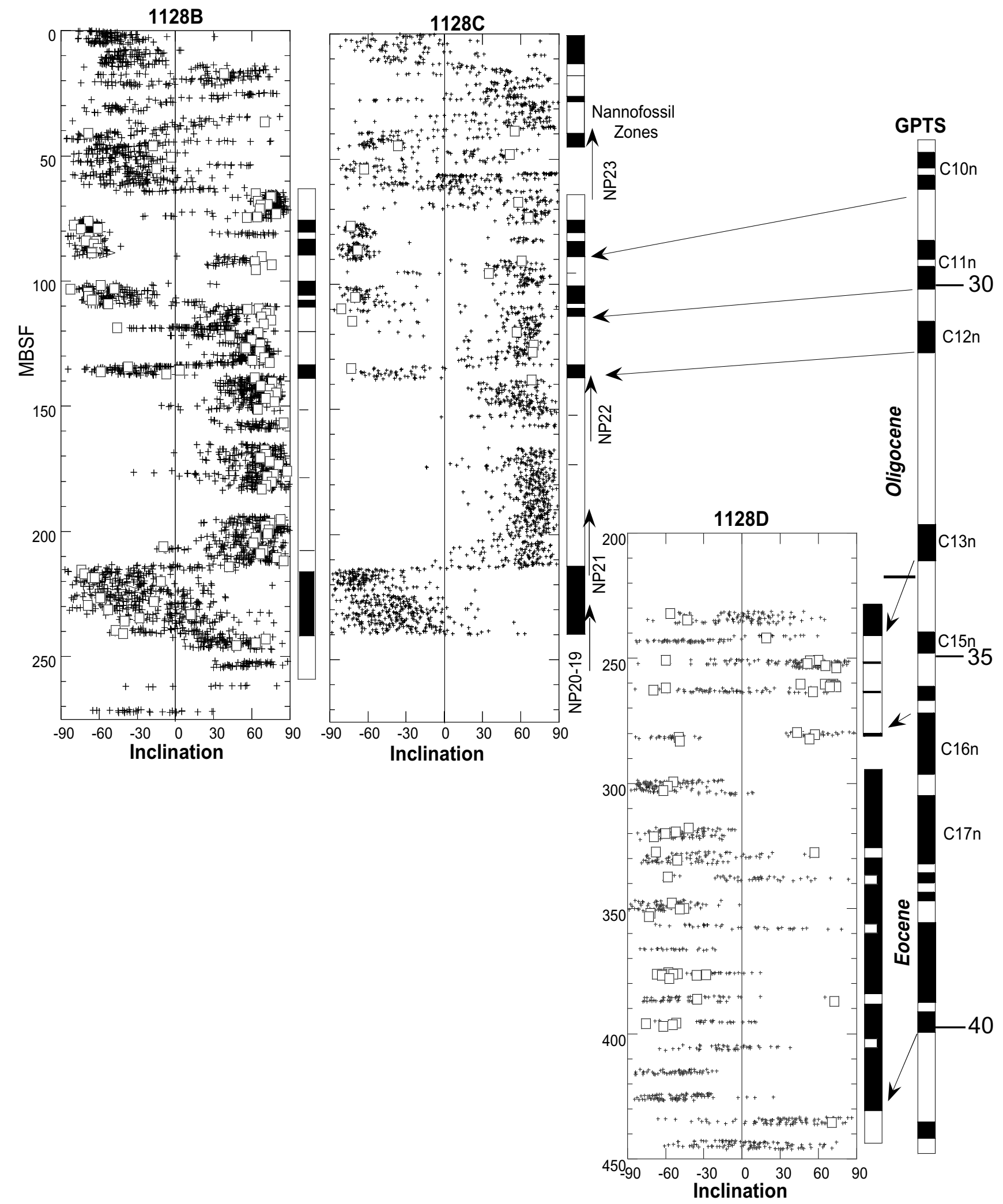

Fig. 8. Magnetostratigraphy results for the Middle Eocene-Lower Oligocene interval of Site 1128.

tensity and relatively high median destructive fields of the NRM, which decrease notably down core. Furthermore, unblocking temperatures are generally distributed; with rapid decay below $300^{\circ} \mathrm{C}$. Measurements carried out on the ship indicate the presence of a weak Verwey transition in sam- ples from cores 1126B-19H and 1126B-29X, thus magnetite is present. Most IRM acquisition curves do not reach saturation with inductions of $0.4 \mathrm{~T}$ (Fig. 11(a)), suggesting the presence of an additional "hard" magnetic phase.

A clear trend in morphology of IRM acquisition curves 

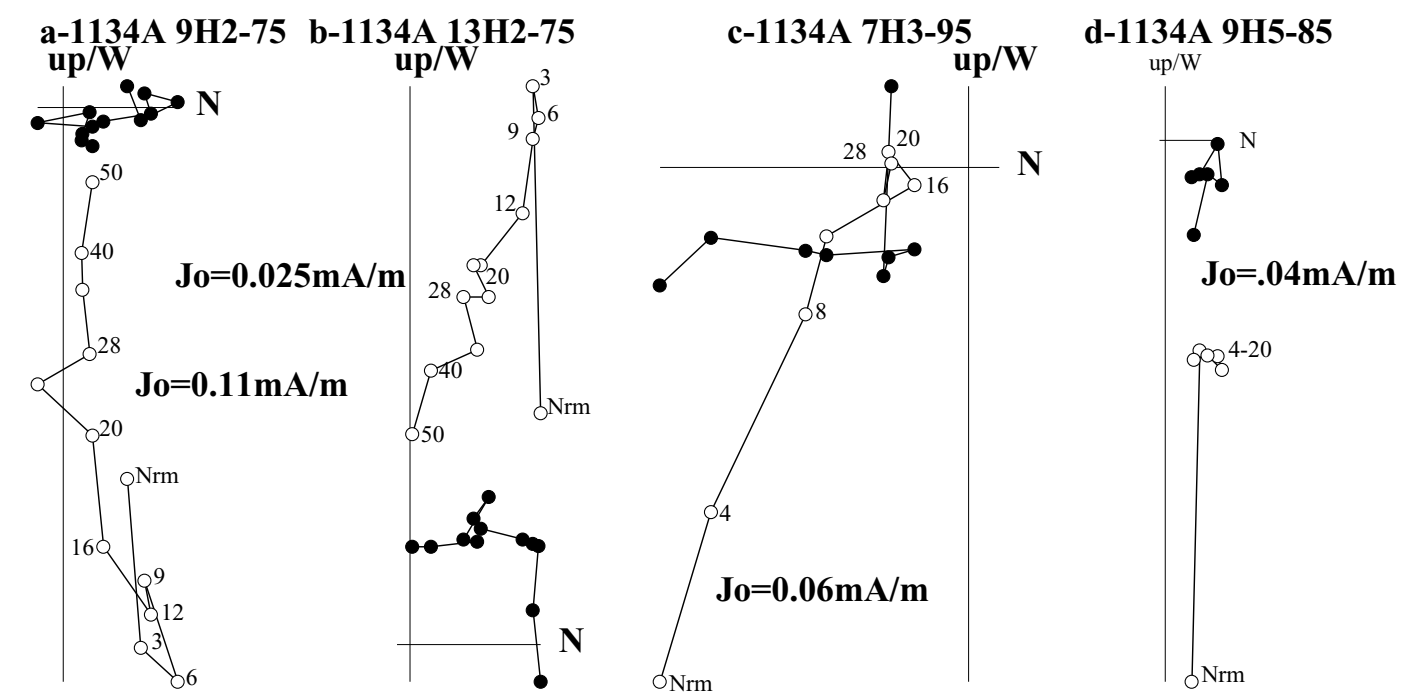

Fig. 9. (a)-(d) Orthogonal demagnetization plots of typical specimens of Site 1134. Open (closed) symbols are projections on the vertical (horizontal) plane.

suggests that contributions to the IRM from a low coercivity phase increase down hole. In both sites, 1126 and 1134, the trend in curve morphology breaks where debrites or slumps have been identified (e.g., samples from Core 1126B-10H, Fig. 11(a)). Debrite and slumped intervals are naturally characterized by poorly defined ChRMs. Figure 11(a) shows that deeper cores, in Middle Miocene and Oligocene sediments, are visibly dominated by a low coercivity phase. The intervals characterized by strong contributions from a low coercivity phase are also characterized by high ARM/IRM ratios, generally greater than 0.2 with values generally increasing down hole. The high ARM/IRM ratio is an indication of the higher relative concentration of single domain over multi-domain grains. Because a decrease in coercivity of the NRM accompanies the increase in the ARM/IRM ratio, is logical to conclude that grain size is not the only variable causing changes in the anhysteretic and isothermal remanence. The relative contribution of the high coercivity phase must also decrease down hole. There is also a weak correlation between intensity of the NRM and the trends described above; samples with high ARM/IRM ratios have higher NRM intensities.

The low coercivity phase is likely to be magnetite, as suggested by NRM demagnetization data and IRM acquisition. The high coercivity phase has the characteristics of a magnetic sulfide, which we interpret to be greigite. The presence of magnetic sulfides is also suggested by the reducing conditions found in the cores (Shipboard Scientific Party, 2000). Decreasing IRM intensity provides the best evidence for the presence of greigite in the carbonate rocks. This was noticed after repeated application of a $0.4 \mathrm{~T}$ induction and immediate measurement of the remanence for several days; the decrease was also accompanied by a decrease in coercivity. The down core increase in the ARM/IRM ratio, suggest that concentrations from coarse multi-domain grains decrease down hole but also suggest that greigite contribution to the NRM are insignificant in the deeper cores. The increase in the ARM/IRM ratio (and the interpreted reduction in greig- ite concentration) at $\sim 100 \mathrm{mbsf}$ corresponds with a zone of strong geochemical gradients such as alkalinity and $\mathrm{SO}_{4}$ concentrations (Shipboard Scientific Party, 2000). A limited set of hysteresis data for samples from Cores $8 \mathrm{H}$ and $11 \mathrm{H}$ for Site 1126 indicates that loops have simple morphologies and hysteresis parameters are typical of pseudo-single domain (PSD) grains (Day et al., 1977).

\subsection{Site 1128}

IRM acquisition curves of sediments from the Middle Eocene-Lower Oligocene sequence of Site 1128 are dominated by contributions from a low coercivity phase, which we interpret to be magnetite. Available data (ARM, IRM, and limited hysteresis data) suggest that magnetite and minor hematite are the principal remanence carriers. Key observations are relatively high MDFs and relatively high coercivity $(>120 \mathrm{mT})$, moderately high $\left(>500^{\circ}\right)$ but distributed unblocking temperatures, and relatively high NRM intensities $\left(\sim 10^{-2} \mathrm{~A} / \mathrm{m}\right)$. IRM acquisition curves suggest, however, that contributions from magnetite to the remanence decrease in relative importance down core. Shallow cores, such as $1128 \mathrm{~B}-3 \mathrm{H}$ and $4 \mathrm{H}$, are dominated by magnetite; intermediate depth cores, such as core 1128B-8H through $11 \mathrm{H}$ have small contributions from a high coercivity phase; whilst, contributions from a high coercivity phase are important in deeper cores (e.g., core 1128D-13R through 17R). This trend is opposite to that observed in the carbonate dominated sequences of Sites 1126 and 1134. The simplest explanation is an increase in the contributions from detrital hematite to the IRM (and NRM, as suggested by AF demagnetization data). Hysteresis data for the carbonaceous clays of Site 1128 indicate grain sizes in the PSD field, but contributions from MD in Eocene clays are evident in the low $\mathrm{Mr} / \mathrm{Mrs}$ values (in the 0.05 to 0.15 range; Day et al., 1977).

\section{Tertiary Paleolatitudes and Australian APWP}

Mean inclinations were calculated for six sample age groups following McFadden and Reid (1982). The Eocene group includes the average of 29 samples for Hole 1128D 

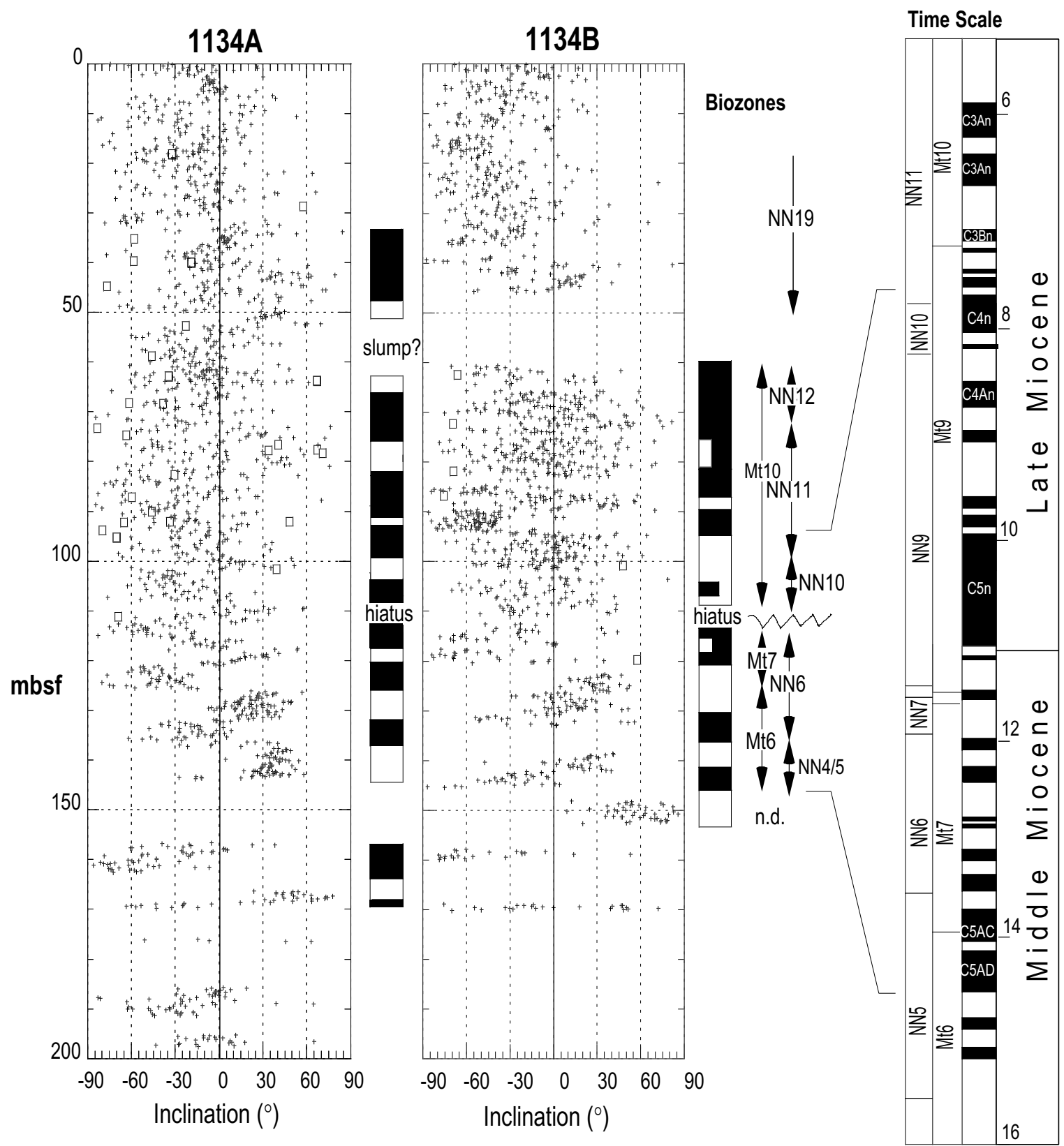

Fig. 10. Magnetostratigraphy results for the Miocene interval of Site 1134. Two possible correlations to the GPTS are shown by solid and dashed lines.

and 5 samples of Hole 1126D. The Early Oligocene group includes 104 samples, all from Site 1128. The Late Oligocene-Early Miocene group includes 11 samples from Hole 1126B, and 8 samples from Hole 1126D. A Middle Miocene estimate is based on data for 20 samples from Hole 1126B, whilst a Late Miocene average was calculated combining 10 samples from Hole $1126 \mathrm{~B}$ with 13 samples from Holes $1134 \mathrm{~A}$ and $1134 \mathrm{~B}$. Inclinations were combined assuming all samples were collected at a common site at $34^{\circ} \mathrm{S} 127.5^{\circ} \mathrm{E}$, and only quality $\mathrm{A}$ and $\mathrm{B}$ samples (samples with $\mathrm{MAD}$ values less than $10^{\circ}$ ) were used in the final calculations. Averages and statistical parameters are listed in Table 1 ; means were calculated for the Pleistocene $(0$ 1.8 Ma), Late Miocene (6-12 Ma), Middle Miocene (14$18 \mathrm{Ma})$, Early Miocene-Late Oligocene (19-27 Ma), Early Oligocene (28-33 Ma), and Middle-Late Eocene (33-40
Ma). A set of Pleistocene specimens (primarily calcareous ooze) subjected to AF demagnetization on board the ship, were used to obtain an estimate of the paleolatitude of the last $\sim 2 \mathrm{Ma}$. This estimate is based on 46 samples representing the Olduvai, Matuyama, Jaramillo, and Brunhes chrons. The mean Pleistocene inclination $\left(-58.2^{\circ} \pm 2.6^{\circ}\right.$, Table 1) agrees within statistical uncertainty with the expected inclination $\left(-55^{\circ}\right)$. The Pleistocene specimens were obtained from depths greater than $\sim 100$ mbsf, and the good agreement between expected and observed inclinations suggests that sediments of the Great Australian Bight are reliable recorders of the paleomagnetic field direction. The five remaining age groups yield mean inclinations $\left(\sim 65^{\circ}\right)$ with relatively high precisions and small uncertainties $(k>30$ and $\alpha_{95}<5^{\circ}$; Table 1$)$. The means are statistically undistinguishable at the $95 \%$ level, but they are distinct from the 

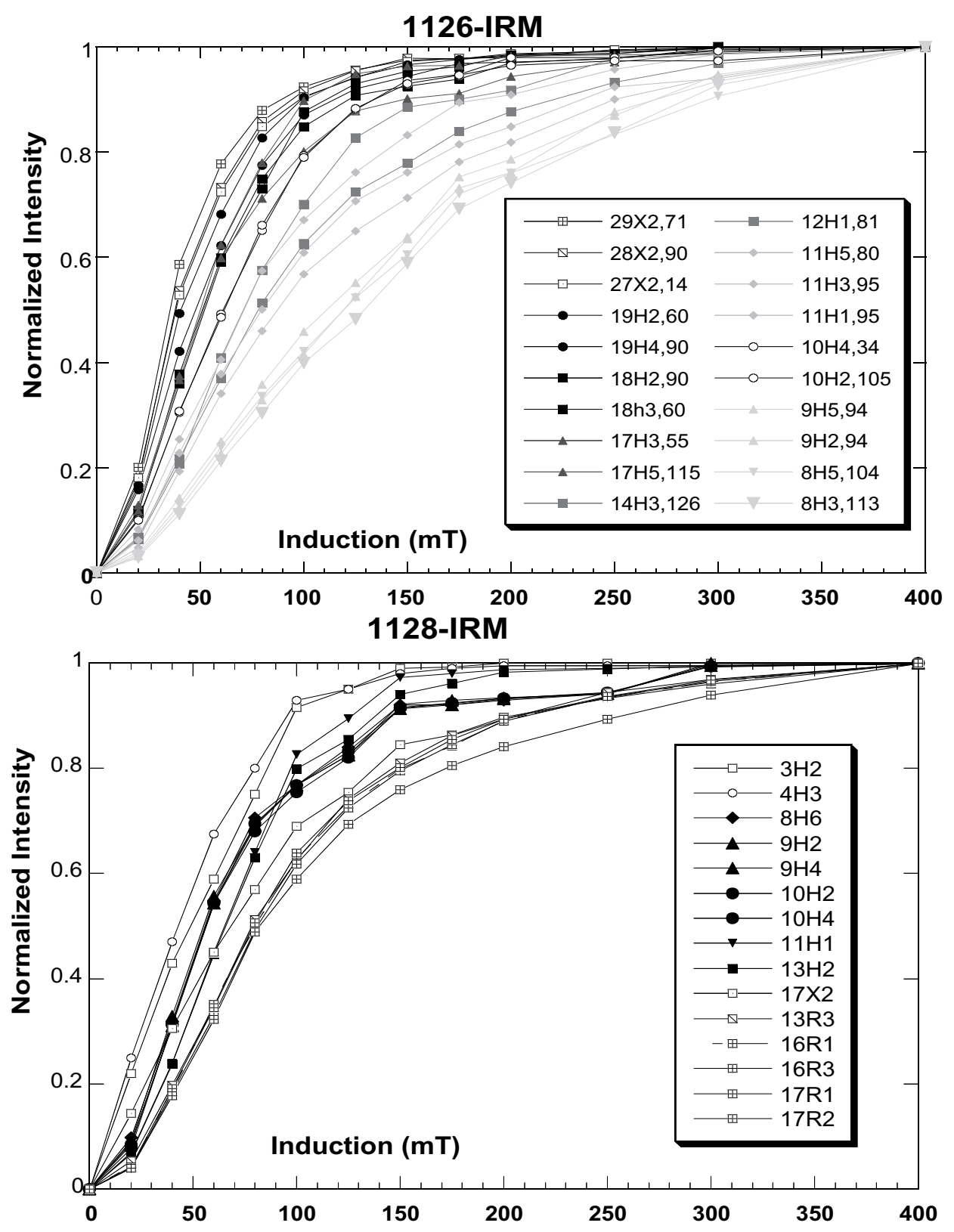

Fig. 11. IRM acquisition curves (normalized) of selected samples from Site 1126 (a) and Site 1128 (b).

Pleistocene mean inclination. The steepest inclination was obtained for the Early Oligocene $\left(\sim 68.6^{\circ}\right)$.

Naturally, inclination shallowing due to sediment compaction is an important concern. Whilst the results for Pleistocene carbonate sediments do not indicate any shallowing, the results for other sediments cannot be evaluated in such simple form. Several studies have demonstrated that clay content is an important factor causing inclination shallowing (Anson and Kodama, 1987), and the effect can be quantified with some confidence using magnetic anisotropy techniques (Tan and Kodama, 1998). Two lines of evidence suggest that errors due to inclination shallowing are small and insignificant. First, chalk and carbonate ooze from the Oligocene sequence sampled in Cores $8 \mathrm{H}$ through $10 \mathrm{H}$ of Site 1128 yield a mean inclination of $67.5^{\circ}\left(n=21, \alpha_{95}=3.3^{\circ}\right)$, which is identical to that observed in the immediately under- lying clay rich sediments $\left(I=66.1^{\circ}, n=19, \alpha_{95}=4.7^{\circ}\right)$. Less convincing, but also supporting our arguments, a small set of Eocene chalk samples from Site 1126 yield a mean inclination of $69.5^{\circ}$ ( $n=5$ samples); this is indistinguishable from the Eocene data for clays and marls from Site $1128\left(I=67.7^{\circ}\right)$. Because the clay content varies greatly between the subsets compared, and because clay content strongly controls inclination shallowing (Tan and Kodama, 1998), the rather trivial differences in inclination observed lead us to believe that shallowing is insignificant. In these comparisons data for normal and reverse polarities were combined.

For most time intervals, the means of positive and negative inclinations do not differ by more than $2^{\circ}$. Notable exceptions are the Early Miocene-Late Oligocene and Middle Miocene age groups, for which mean inclinations for normal 
Table 1. Mean inclination and paleolatitude for Cenozoic sediments of ODP Leg 182.

\begin{tabular}{|c|c|c|c|c|c|}
\hline Age & Inclination & $n$ & $\alpha_{95}$ & $k$ & Paleolatitude \\
\hline \multicolumn{6}{|c|}{ Pleistocene (0-1.8 Ma) } \\
\hline Normal & -58.7 & 34 & 3.2 & 58.7 & \\
\hline Reverse & 56.8 & 12 & 4.9 & 85.9 & \\
\hline Combined & -58.2 & 46 & 2.6 & 63.9 & -38.9 \\
\hline \multicolumn{6}{|c|}{ Late Miocene (6-12 Ma) } \\
\hline Normal & -65.5 & 10 & 9.8 & 29.8 & \\
\hline Reverse & 66.3 & 13 & 7.3 & 36.7 & \\
\hline Combined & -65.9 & 23 & 5.6 & 33.3 & -48.2 \\
\hline \multicolumn{6}{|c|}{ Middle Miocene (14-18 Ma) } \\
\hline Normal & -61.6 & 8 & 7.5 & 67.9 & \\
\hline Reverse & 70.2 & 12 & 2.4 & 70.2 & \\
\hline Combined & -66.8 & 20 & 3.8 & 76.4 & -49.4 \\
\hline \multicolumn{6}{|c|}{ Early Miocene-Late Oligocene (19-27 Ma) } \\
\hline Normal & -55.8 & 7 & 8.2 & 72.3 & \\
\hline Reverse & 70.0 & 12 & 6.1 & 57.5 & \\
\hline Combined & -64.8 & 19 & 6.3 & 32.0 & -46.7 \\
\hline \multicolumn{6}{|c|}{ Early Oligocene (28-33 Ma) } \\
\hline Normal & -67.4 & 32 & 3.2 & 66.0 & \\
\hline Reverse & 69.1 & 72 & 4.9 & 56.3 & \\
\hline Combined & -68.6 & 104 & 2.1 & 60.0 & -51.8 \\
\hline \multicolumn{6}{|c|}{ Middle-Late Eocene (33-40 Ma) } \\
\hline Normal & -68.9 & 20 & 4.2 & 61.2 & \\
\hline Reverse & 66.1 & 14 & 5.1 & 60.5 & \\
\hline Combined & -67.7 & 34 & 3.2 & 60.6 & -50.7 \\
\hline
\end{tabular}

Here $n$ is the number of samples used in the mean calculation, $\alpha_{95}$ and $k$ are the the corresponding confidence interval and precision parameter, respectively.

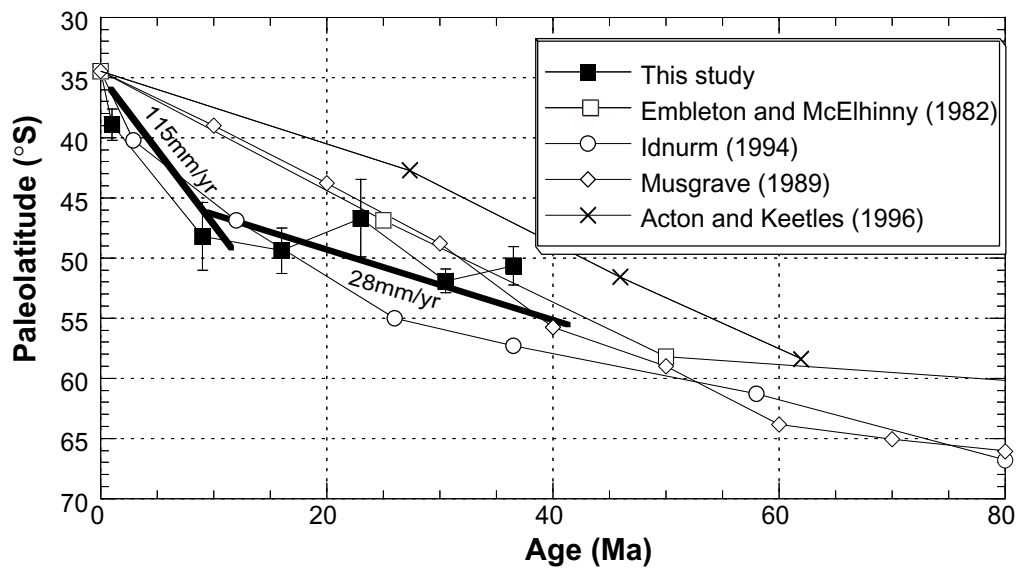

Fig. 12. Predicted versus observed (closed symbols with error bars) paleolatitudes for an arbitrary site in the Eyre Terrace of the Great Australian Bight. Bold lines are least-square fits to the paleolatitude data for the intervals $40-10 \mathrm{Ma}$ and 10-0 Ma, with the corresponding rates of latitudinal (northward) motion.

and reverse polarities differ significantly. Normal polarity means (negative inclinations) are of shallower inclination, which suggests that unremoved present day field bias can explain the difference observed. The combined mean of nor- mal and reverse directions may not be significantly affected by this bias if the number of reverse and normal directions used to calculate the mean is similar, effectively canceling the effect of the bias. 
Mean inclinations constrain the locus of the paleomagnetic pole along a small circle centered on the sampling site; the radius of the small circle is defined by the colatitude via the dipole formula. For a simpler comparison, expected paleolatitudes for the same central site were calculated using available models of the Australian APWP. Expected paleolatitudes indicate a latitudinal shift of $\sim 30^{\circ}$ during Cenozoic time, which implies that progressively younger sediments of the Australian Bight should record ever more shallow inclinations. In detail, Fig. 12 shows that the APWPs of Embleton and McElhinny (1982) and Musgrave (1989) predict gradual and roughly constant latitudinal shift, reaching a paleolatitude of $\sim 40^{\circ}$ by $\sim 10$ million years ago. The APWP proposed by Idnurm (1994) predicts that those paleolatitudes are not reached until about 5 million years ago and indicates far more rapid latitudinal change since the Late Miocene (since about $10 \mathrm{Ma}$ ). This translates into acceleration in the Neogene rate of northward drift with important geodynamic implications.

Inclination data for Miocene sediments of Leg 182 support a rapid latitudinal change since the Late Miocene. Linear fits to paleolatitude estimates based on our inclination data and paleolatitude estimates based on paleomagnetic pole data of Idnurm (1994), for the last 40 million years, suggest that the rate of northward drift of the Australian continent changed from $\sim 28 \mathrm{~mm} / \mathrm{yr}$ in Middle Eocene-Middle Miocene times to $\sim 115 \mathrm{~mm} / \mathrm{yr}$ since the Late Miocene. Despite of our discussion above, because anisotropy measurements were not carried out to estimate inclination errors due to compaction, we must allow for possibly higher inclinations in the Eocene portion of the record - where inclination data were derived from mostly clay-rich sediments. Steeper inclinations in the Eocene, as suggested by Idnurm (1994) would make the change in northward drift in the Late Miocene less dramatic, but would not remove it. Acceleration of the Australian plate in the Late Miocene is indirectly supported by independent geologic data, such as: (1) ophiolite obduction in the Banda Arc region starting ca. 9.5 Ma and collision of the Banda Arc with the Australian margin 8-3 Ma (Linthout et al., 1997); (2) regional uplift across the southeast Australian margin in the Late Miocene (Dickinson et al., 2000); and, (3) the apparent termination of tectonic rotation of terranes along the Australia-Philippine Sea plate margin (e.g. Fuller et al., 1999; Ali and Hall, 1995). The rate of northward drift we have calculated is faster than suggested in various tectonic models of Southeast Asia (e.g., Lee and Lawver, 1995).

\section{Conclusions}

Cenozoic deep-sea sediments of ODP Leg 182 in the Great Australian Bight yield a well-defined ChRM that resides in magnetite and magnetic sulfides. Inclination data provide paleolatitude estimates for Middle-Late Eocene (40-33 Ma; $50.7^{\circ} \mathrm{S} \pm 1.6^{\circ}$ ), Early Oligocene (33-28 Ma; $\left.51.8^{\circ} \mathrm{S} \pm 1^{\circ}\right)$, Late Oligocene-Early Miocene (27-19 Ma $46.7^{\circ} \mathrm{S} \pm 3.2^{\circ}$ ), Middle Miocene (18-14 Ma; 49.4 ${ }^{\circ} \mathrm{S} \pm$ $\left.1.9^{\circ}\right)$, Late Miocene (12-6 Ma; $\left.48.3^{\circ} \mathrm{S} \pm 2.8^{\circ}\right)$, and Pleistocene $\left(0-1.8 \mathrm{Ma} ; 38.9^{\circ} \mathrm{S} \pm 1.3^{\circ}\right)$. When observed paleolatitudes (or inclinations) are compared with those expected using competing versions of the Australian APWP, the best agreement is found with the Late Miocene path proposed by Idnurm $(1994,1985)$, whereas our estimate of the Oligocene-Miocene pole is intermediate between the poles of Musgrave (1989) and Idnurm (1994). Together, paleolatitude data from this study and paleolatitudes determined using Idnurm's pole data indicate slow northward motion from Eocene to Middle Miocene time, and an abrupt acceleration since the Late Miocene. Fast northward motion of Australia in the last $\sim 10$ Ma coincides with tectonic events in Southeast Asia and the effective closure and shallowing of the Indonesia Seaway. Oligocene paleolatitude data also supports the reconstruction of a wide ocean $(>1500 \mathrm{~km})$ between Australia and SE Asia (e.g., Lee and Lawver, 1995).

Acknowledgments. This research used samples and data provided by the Ocean Drilling Program (ODP). ODP is sponsored by the U.S. National Science Foundation (NSF) and participating countries under management of Joint Oceanographic Institutions (JOI), Inc. Funding for this research was provided by JOI-USSSP. We also thank John Geissman and Joshua Johnson for their support in the paleomagnetic laboratory at the University of New Mexico, and the journal's referees K. P. Kodama and P. W. Schmidt, and associate editor H. Tanaka for their reviews. Special thanks to G. D. Acton for comments to a previous version of this manuscript.

\section{References}

Acton, G. D., Apparent polar wander of India since the Cretaceous with implications for regional tectonics and true polar wander, Mem. Geol. Soc. India, 44, 129-175, 1999.

Acton, G. D. and W. A. Keetles, Geologic and paleomagnetic constraints on the formation of weathered profiles near Inverell, eastern Australia, Palaeogeography, Palaeoclimatology, Palaeoecology, 126, 211-225, 1996.

Ali, J. R. and R. Hall, Evolution of the boundary between the Philippine Sea plate and Australia, paleomagnetic evidence from eastern Indonesia, Tectonophys., 251, 251-276, 1995.

Anson, G. L. and K. P. Kodama, Compaction-induced shallowing of the post-depositional remanent magnetization in a synthetic sediment, Geophys. J. R. Astron. Soc., 88, 673-692, 1987.

Berggren, W. A., D. V. Kent, C. C. Swisher, and M. P. Aubrey, Revised Cenozoic geochronology and chronostratigraphy, in Geochronology Time Scales and Global Stratigraphic correlation, SEPM Special Publication, 54, pp. 131-212, 1995.

Cande, S. C. and D. V. Kent, A revised calibration of the geomagnetic polarity timescale for the Late Cretaceous and Cenozoic, J. Geophys. Res., 100, 6093-6095, 1995.

Day, R., M. Fuller, and V. A. Schmidt, Hysteresis properties of titanomagnetites: grain-size and compositional dependence, Phys. Earth Planet. Int., 13, 260-267, 1977.

Dickinson, J. A., M. W. Wallace, G. R. Holdgate, S. J. Gallagher, and L. Thomas, Late Miocene uplift across the Southeast Australian margin, 14th Victorian universities earth sciences conference-Abstracts, Geol. Soc. Australia, 62, 21, 2000.

Embleton, B. J. J. and M. W. McElhinny, Marine magnetic anomalies, palaeomagnetism and the drift history of Gondwanaland, Earth Planet. Sci. Lett., 58, 141-150, 1982.

Feary, D. A., A. C. Hine, M. J. Malone, et al., Proc. ODP, Init. Repts., 182 (CD-ROM), College Station, TX, Ocean Drilling Program, Texas A\&M University, 2000.

Fuller, M., R. S. Molina-Garza, and Shipboard Scientific Party, AppendixMagnetic Experiments, in Proc. ODP, Init. Repts., 182 (CD-ROM), edited by D. A. Feary, A. C. Hine, M. J. Malone, et al., College Station, TX, Ocean Drilling Program, Texas A\&M University, 2000.

Fuller, M., J. R. Ali, S. J. Moss, G. M. Frost, B. Richter, and A. Mahfi, 1999, Paleomagnetism of Borneo, J. Asian Earth Sci., 17, 3-24, 1999.

Idnurm, M., Late Mesozoic and Cenozoic palaeomagnetism of Australia I, A redetermined apparent polar wander path, Geophys. J. R. Astron. Soc., 83, 399-418, 1985 .

Idnurm, M., New Late Eocene pole for Australia, time averaging of remanence directions, and palaeogeographic reference systems, Geophys. J. Int., 117, 827-833, 1994. 
Kirschvink, J. L., The least-squares line and plane and the analysis of paleomagnetic data: examples from Siberia and Morroco, Geophys. J. R. Astron. Soc., 62, 699-718, 1980.

Klootwijk, C. T., J. S. Gee, J. W. Pierce, and G. M. Smith, Constraints on the India-Asia convergence: Paleomagnetic results from Ninetyeast Ridge, in Proc. ODP Sci. Results, 121, edited by J. Weissel, J. Pierce, E. Taylor, J. Alt, et al., College Station, TX, pp. 777-882, 1991.

Kodama, K. and J. Ogg, Motion of the Australian Plate from sediment paleoinclinations, Early Cretaceous through Holocene, Proc. Ocean Drilling Program, Scientific Results, 123, 549-554, 1992.

Lee, T. Y. and L. A. Lawver, Cenozoic plate reconstruction of Southeast Asia, Tectonophys., 251, 85-138, 1995.

Linthout, K., H. Helmers, and J. Sopaheluwakan, Late Miocene obduction and microplate migration around the southern Banda Sea and the closure of the Indonesian Seaway, Tectonophys., 281, 17-30, 1997.

McFadden, P. L. and M. W. McElhinny, Classification of the reversal test in palaeomagnetism, Geophys. J. Int., 103, 725-729, 1990.

McFadden, P. L. and A. B. Reid, Analysis of paleomagnetic inclination data, Geophys. J. R. Astron. Soc., 69, 307-319, 1982.

Musgrave, R. J., A weighted least-square fit of the Australian apparent polar wander path for the last 100 Myr, Geophysical Journal, 96, 231-243, 1989.

Shipboard Scientific Party, Leg 182 Summary, in Proc. ODP, Init. Repts., 182, edited by D. A. Feary, A. C. Hine, M. J. Malone, et al., College Station, TX (Ocean Drilling Program), pp. 1-58, 2000.

Tan, X. and K. P. Kodama, Compaction-corrected inclinations from southern California Cretaceous marine sedimentary rock indicate no paleolatitudinal offset for the Peninsular Ranges terrane, J. Geophys. Res., 103, 27169-27192, 1998.

Zijderveld, J. D. A., A.C. demagnetization of rocks: Analysis of results, in Methods in Rock Magnetism and Paleomagnetism, edited by D. W. Collinson, K. M. Creer, and S. K. Runcorn, pp. 254-286, Elsevier, Amsterdam, 1967.

R. S. Molina Garza (e-mail: rmolina@unicit.unam.mx) and M. Fuller 